\title{
Photoinduced Phase Transitions in Rod-shaped Azobenzene with Different Alkyl Chain Length
}

\author{
Yasuo Norikane ${ }^{1 *}$, Emi Uchida ${ }^{1}$, Satoko Tanaka ${ }^{1}$, Kyoko Fujiwara ${ }^{1}$, Hideki Nagai ${ }^{2}$, and \\ Haruhisa Akiyama ${ }^{3}$
}

\author{
${ }^{1}$ Electronics and Photonics Research Institute, National Institute of Advanced Industrial Science \\ and Technology (AIST), Central 5, 1-1-1, Higashi, Tsukuba, Ibaraki 305-8565, Japan \\ ${ }^{2}$ Research Institute for Measurement and Analytical Instrumentation, National Institute of \\ Advanced Industrial Science and Technology (AIST), 16-1, Onogawa, Tsukuba, Ibaraki 305-8569, \\ Japan \\ ${ }^{3}$ Research Institute for Sustainable Chemistry, National Institute of Advanced Industrial Science \\ and Technology (AIST), Central 5, 1-1-1, Higashi, Tsukuba, Ibaraki 305-8565, Japan
}

\begin{abstract}
The direct and reversible solid-liquid phase transitions by photochromic reactions at constant temperature are of interest because of potential applications in reusable adhesives, photoresists and so on. We report photoinduced solid-liquid phase transitions in rod-shaped azobenzenes, possessing a methyl group at the 3-position and alkoxy groups with different chain length $(\mathrm{Cn}=1-18)$ at the 4- and 4'-positions. Thermal property, photochemical property, and adhesive properties were investigated. We found that the azobenzenes with alkyl chain length of 6-10 showed relatively fast photoinduced solid-liquid phase transition than that with shorter $(\mathrm{Cn}=1-5)$ and longer $(\mathrm{Cn}=11-18)$ ones. Tensile shear strength were measured by using these azobenzenes as photoresponsive adhesives. Irradiation with UV light $(365 \mathrm{~nm})$ induced the phase transition to the liquid phase and the adhesion strength values decreased to almost zero. Then the irradiation with visible light $(450 \mathrm{~nm})$ recovered the adhesion strength.
\end{abstract}

Keywords: azobenzene, isomerization, photochromism, solid-liquid phase transition, dismantlable adhesives

\section{Introduction}

Photochromic reaction such as photoisomerization of azobenzene has been widely utilized in switching phases of liquid crystals [1-3], gels [2,4], and changing fluidity of polymer surfaces $[5,6]$. Characteristics of these photoresponsive materials is that state of matter can be controlled by photoirradiation without changing the temperature of the materials.

These above mentioned examples are consisting of relatively soft materials so that the photoisomerization of azobenzene is basically possible because there is sufficient free volume around azobenzene moiety. On the other hand, the photoisomerization (trans-to-cis) of azobenzene in the crystal phase had been long believed not to occur [7] till it was found to take place on the surface $[8,9]$.

Recently, photoinduced solid-liquid phase transitions by photochromic reactions has been of great interest since our first report of the photoinduced phase transitions between solid (crystal) and liquid phase at room temperature in macrocyclic azobenzene [10-13]. Similar phenomena have been reported by several groups in azobenzene derivatives [14-17] and a spiropyran [18]. In an application point of view, this phase transition is of importance because this kind of phase transition material can be potentially be used in reusable light adhesives (dismantlable adhesives), photoresists, and 
other functional materials. Actually, it has been demonstrated that azobenzene-based materials can be used as dismantlable adhesives, that drastic decrease and recovery of the adhesion force were observed by the irradiation with ultraviolet and visible light, respectively [19-22].

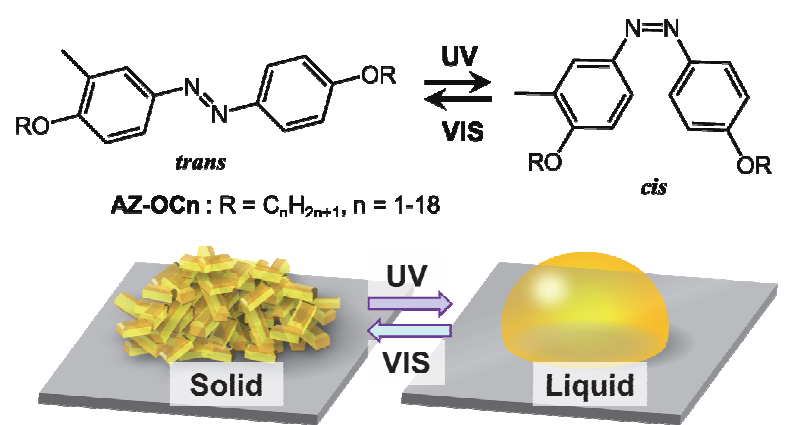

Fig. 1. Molecular structure of AZ-OCn (top) and schematic diagram for the photoinduced solid-liquid phase transition (bottom).

Previously, we have reported a molecular design criteria for the solid-liquid phase transition in rod-shaped azobenzenes and demonstrated to use an azobenzene as a photoresist [23]. Substitution of a methyl group at the 3-position to azobenzenes having para-dialkoxy groups (Figure 1, AZ-OCn; $\mathrm{n}=$ $6,10,12)$ drastically altered the phase transition photoresponse compared to the azobenzenes possessing two methyl groups at the 3- and 3'-positions or no methyl groups. These results prompted us to focus on the molecular skeleton with different chain length of the alkoxy groups at the 4- and 4'-positions $(\mathrm{Cn}=1-18)$. A method to evaluate the photoinduced phase transition has not been established.

The purpose of this study consists of three components. First, to clarify the effect of the alkyl chain length on thermal and photoinduced phase transition properties. Second, to establish the method for the evaluation of photoinduced phase transition. Finally, to demonstrate these compounds as reusable photofunctional adhesives.

\section{Experimental}

\subsection{Materials}

Synthesis of 4,4'-dihydroxy-3methylazobenzene (AZ-OH), 4,4'dihexyloxy-3-methylazobenzene (AZ-OC6),
4,4'- didecyloxy-3-methylazobenzene (AZOC10), 4,4'-didodecyloxy-3methylazobenzene (AZ-OC12) were reported previously [23].

\section{4,4'-Dimetyloxy-3-methylazobenzene} (AZ-OC1)

A solution of AZ-OH $(0.228 \mathrm{~g}, 1.0 \mathrm{mmol})$, methyl p-toluenesulfonate $(0.41 \mathrm{~g}, 2.2 \mathrm{mmol})$, and potassium carbonate $(1.11 \mathrm{~g}, 8.0 \mathrm{mmol})$ in acetonitrile $(10 \mathrm{~mL})$ was refluxed with stirring for $5 \mathrm{~h}$ under nitrogen atmosphere. Then, the mixture was allowed to cool to rt and the solvent was removed under reduced pressure. The resulting residue was extracted with chloroform and organic layer was collected. The residue was purified by GPC and recrystallized from ethyl acetate/hexane to give 4,4'-dimethoxy-3-methylazobenzene (AZ-OC1) (0.22 g, 86\%) as orange crystalline solid. ${ }^{1} \mathrm{H}$ NMR $\left(400 \mathrm{MHz}, \mathrm{CDCl}_{3}\right): \delta 7.85(\mathrm{~d}$, $J=7.8 \mathrm{~Hz}, 2 \mathrm{H}), 7.75-7.71(\mathrm{~m}, 2 \mathrm{H}), 6.98(\mathrm{~d}, J$ $=6.8 \mathrm{~Hz}, 2 \mathrm{H}), 6.91(\mathrm{~d}, J=8.5 \mathrm{~Hz}, 1 \mathrm{H}), 3.89$ $(\mathrm{s}, 3 \mathrm{H}), 3.87(\mathrm{~s}, 3 \mathrm{H}), 2.27(\mathrm{~s}, 3 \mathrm{H}) .{ }^{13} \mathrm{C} \mathrm{NMR}$ $\left(125 \mathrm{MHz}, \mathrm{CDCl}_{3}\right): \delta 161.4,159.9,147.2$, $146.6,127.4,124.2,123.5,123.4,114.1$, $109.7,55.6,55.5,16.3$.

\section{4,4'-Diethyloxy-3-methylazobenzene}

\section{(AZ-OC2)}

A solution of AZ-OH (0.228 g, $1.0 \mathrm{mmol})$, ethyl $p$-toluenesulfonate $(0.44 \mathrm{~g}, 2.2 \mathrm{mmol})$, and potassium carbonate $(1.11 \mathrm{~g}, 8.0 \mathrm{mmol})$ in acetonitrile $(10 \mathrm{~mL})$ was refluxed with stirring for $5 \mathrm{~h}$ under nitrogen atmosphere. Then, the mixture was allowed to cool to $\mathrm{rt}$ and the resulting residue was washed with acetone. The solvent was removed under reduced pressure. The resulting residue was extracted with chloroform and organic layer was collected. The residue was purified by GPC to give 4,4'-diethyloxy-3-methylazobenzene

(AZ-OC2) $(0.24 \mathrm{~g}, 85 \%)$ as orange crystalline solid. ${ }^{1} \mathrm{H}$ NMR $\left(400 \mathrm{MHz}, \mathrm{CDCl}_{3}\right): \delta 7.84(\mathrm{~d}$, $J=6.8 \mathrm{~Hz}, 2 \mathrm{H}), 7.73-7.70(\mathrm{~m}, 2 \mathrm{H}), 6.96(\mathrm{~d}, J$ $=6.9 \mathrm{~Hz}, 2 \mathrm{H}), 6.88(\mathrm{~d}, J=9.3 \mathrm{~Hz}, 1 \mathrm{H})$, 4.13-4.07 (m, 4H), $2.28(\mathrm{~s}, 3 \mathrm{H}), 1.46-1.42(\mathrm{~m}$, $6 \mathrm{H}) .{ }^{13} \mathrm{C}$ NMR $\left(125 \mathrm{MHz}, \mathrm{CDCl}_{3}\right): \delta 160.8$, $159.3,147.1,146.5,127.5,124.2,123.5$, $123.3,114.6,110.6,63.8,63.8,16.4,14.8$, 14.8 . 


\section{4,4'-Dipropyloxy-3-methylazobenzene \\ (AZ-OC3)}

A solution of AZ-OH (0.228 g, $1.0 \mathrm{mmol})$, 1-bromopropane $(0.271 \mathrm{~g}, 2.2 \mathrm{mmol})$, and potassium carbonate $(1.11 \mathrm{~g}, 8.0 \mathrm{mmol})$ in acetonitrile $(10 \mathrm{~mL})$ was refluxed with stirring for $5 \mathrm{~h}$. Then, the mixture was allowed to cool to $\mathrm{rt}$ and the resulting residue was washed with acetone. The solvent was removed under reduced pressure. The resulting residue was extracted with chloroform and organic layer was collected. The residue was purified by GPC to give 4,4'-dipropyloxy-3-methylazobenzene

(AZ-OC3) $(0.28 \mathrm{~g}, 90 \%)$ as orange crystalline solid. ${ }^{1} \mathrm{H}$ NMR $\left(400 \mathrm{MHz}, \mathrm{CDCl}_{3}\right): \delta 7.84(\mathrm{~d}$, $J=6.9 \mathrm{~Hz}, 2 \mathrm{H}), 7.73-7.70(\mathrm{~m}, 2 \mathrm{H}), 6.96(\mathrm{~d}, J$ $=6.9 \mathrm{~Hz}, 2 \mathrm{H}), 6.88(\mathrm{~d}, J=6.0 \mathrm{~Hz}, 1 \mathrm{H})$, 4.01-3.96 (m, 4H), $2.28(\mathrm{~s}, 3 \mathrm{H}), 1.89-1.78(\mathrm{~m}$, 4H), 1.08-1.03 (m, 6H). ${ }^{13} \mathrm{C}$ NMR (125 MHz, $\left.\mathrm{CDCl}_{3}\right): \delta 161.0,159.4,147.0,146.4,127.5$, $124.2,123.5,123.4,114.7,110.6,69.8,69.7$, $22.7,22.6,16.3,10.6,10.5$.

\section{4,4'-Dibutyloxy-3-methylazobenzene (AZ-OC4)}

A solution of AZ-OH $(0.228 \mathrm{~g}, 1.0 \mathrm{mmol})$, 1-bromobutane $(0.301 \mathrm{~g}, 2.2 \mathrm{mmol})$, and potassium carbonate $(1.11 \mathrm{~g}, 8.0 \mathrm{mmol})$ in acetonitrile $(10 \mathrm{~mL})$ was refluxed with stirring for $5 \mathrm{~h}$. Then, the mixture was allowed to cool to $\mathrm{rt}$ and the resulting residue was washed with acetone. The solvent was removed under reduced pressure. The resulting residue was extracted with chloroform and organic layer was collected. The residue was purified by GPC to give 4,4'-dibutyloxy-3-methylazobenzene

(AZ-OC4) (0.32 g, 94\%) as orange crystalline solid. ${ }^{1} \mathrm{H}$ NMR $\left(400 \mathrm{MHz}, \mathrm{CDCl}_{3}\right): \delta 7.83(\mathrm{~d}$, $J=6.9 \mathrm{~Hz}, 2 \mathrm{H}), 7.73-7.70(\mathrm{~m}, 2 \mathrm{H}), 6.96(\mathrm{~d}, J$ $=6.9 \mathrm{~Hz}, 2 \mathrm{H}), 6.89(\mathrm{~d}, J=9.4 \mathrm{~Hz}, 1 \mathrm{H})$, 4.05-4.00 (m, 4H), $2.27(\mathrm{~s}, 3 \mathrm{H}), 1.82-1.75(\mathrm{~m}$, $4 \mathrm{H})$, 1.55-1.47 (m, 4H), 1.00-0.96 (m, 6H). ${ }^{13} \mathrm{C}$ NMR $\left(125 \mathrm{MHz}, \mathrm{CDCl}_{3}\right): \delta 161.1,159.4$, $147.0,146.4,127.5,124.2,123.5,123.4$, $114.7,110.1,68.0,67.9,31.4,31.3,19.3,19.2$, $16.3,13.9,13.8$.

\section{4,4'-Dipentyloxy-3-methylazobenzene (AZ-OC5)}

A solution of AZ-OH (0.228 g, $1.0 \mathrm{mmol})$, 1-bromobutane $(0.332 \mathrm{~g}, 2.2 \mathrm{mmol})$, and potassium carbonate $(1.11 \mathrm{~g}, 8.0 \mathrm{mmol})$ in acetonitrile $(10 \mathrm{~mL})$ was refluxed with stirring for $5 \mathrm{~h}$. Then, the mixture was allowed to cool to $\mathrm{rt}$ and the resulting residue was washed with acetone. The solvent was removed under reduced pressure. The resulting residue was extracted with chloroform and organic layer was collected. The residue was purified by GPC to give 4,4'-dipentyloxy-3-methylazobenzene

(AZ-OC5) (0.33 g, 90\%) as orange crystalline solid. ${ }^{1} \mathrm{H}$ NMR $\left(400 \mathrm{MHz}, \mathrm{CDCl}_{3}\right): \delta 7.83(\mathrm{~d}$, $J=6.9 \mathrm{~Hz}, 2 \mathrm{H}), 7.72-7.70(\mathrm{~m}, 2 \mathrm{H}), 6.96(\mathrm{~d}, J$ $=6.9 \mathrm{~Hz}, 2 \mathrm{H}), 6.88(\mathrm{~d}, J=9.4 \mathrm{~Hz}, 1 \mathrm{H})$, 4.04-3.99 (m, 4H), $2.27(\mathrm{~s}, 3 \mathrm{H}), 1.85-1.77(\mathrm{~m}$, $4 \mathrm{H}), 1.49-1.36(\mathrm{~m}, 8 \mathrm{H}), 0.95-0.91(\mathrm{~m}, 6 \mathrm{H})$.

${ }^{13} \mathrm{C}$ NMR $\left(125 \mathrm{MHz}, \mathrm{CDCl}_{3}\right): \delta 161.0,159.4$, $147.0,146.4,127.5,124.2,123.5,123.4$, $114.6,110.5,68.3,68.3,29.0,28.9,28.3,28.2$, $22.4,16.4,14.0,14.0$.

\section{4,4'-Diheptyloxy-3-methylazobenzene (AZ-OC7)}

A solution of AZ-OH (0.182 g, $0.8 \mathrm{mmol})$, 1-bromoheptane $(0.322 \mathrm{~g}, 1.8 \mathrm{mmol})$, and potassium carbonate $(0.88 \mathrm{~g}, 6.4 \mathrm{mmol})$ in acetonitrile $(10 \mathrm{~mL})$ was refluxed with stirring for $6 \mathrm{~h}$. Then, the mixture was allowed to cool to $\mathrm{rt}$ and the resulting residue was washed with acetone. The solvent was removed under reduced pressure. The resulting residue was extracted with chloroform and organic layer was collected. The residue was purified by GPC to give 4,4'-diheptyloxy-3-methylazobenzene

(AZ-OC7) (0.30 g, 89\%) as orange crystalline solid. ${ }^{1} \mathrm{H}$ NMR $\left(400 \mathrm{MHz}, \mathrm{CDCl}_{3}\right): \delta 7.83(\mathrm{~d}$, $J=9.0 \mathrm{~Hz}, 2 \mathrm{H}), 7.72-7.70(\mathrm{~m}, 2 \mathrm{H}), 6.96(\mathrm{~d}, J$ $=9.0 \mathrm{~Hz}, 2 \mathrm{H}), 6.88(\mathrm{~d}, J=9.3 \mathrm{~Hz}, 1 \mathrm{H})$, 4.04-3.99 (m, 4H), 2.27 (s, 3H), 1.85-1.77 (m, $4 \mathrm{H}), 1.52-1.30(\mathrm{~m}, 16 \mathrm{H}), 0.90-0.86(\mathrm{~m}, 6 \mathrm{H})$. ${ }^{13} \mathrm{C}$ NMR $(125 \mathrm{MHz}, \mathrm{CDCl} 3): \delta 161.1,159.4$, $147.0,146.4,127.5,124.2,123.5,123.4,114.6$, $110.5,68.3,68.3,31.8,31.8,29.3,29.2,29.0$, 26.1, 26.0, 22.6, 16.4, 14.1.

\section{4,4'-Dioctyloxy-3-methylazobenzene (AZ-OC8)}

A solution of AZ-OH (0.182 g, $0.8 \mathrm{mmol})$, 1-bromooctane $(0.347 \mathrm{~g}, 1.8 \mathrm{mmol})$, and potassium carbonate $(0.88 \mathrm{~g}, 6.4 \mathrm{mmol})$ in acetonitrile $(10 \mathrm{~mL})$ was refluxed with stirring for $6 \mathrm{~h}$. Then, the mixture was 
allowed to cool to $\mathrm{rt}$ and the resulting residue was washed with acetone. The solvent was removed under reduced pressure. The resulting residue was extracted with chloroform and organic layer was collected. The residue was purified by GPC to give 4,4'-dioctyloxy-3-methylazobenzene

(AZ-OC8) $(0.31 \mathrm{~g}, 86 \%)$ as orange crystalline solid. ${ }^{1} \mathrm{H}$ NMR $\left(400 \mathrm{MHz}, \mathrm{CDCl}_{3}\right): \delta 7.83(\mathrm{~d}, J$ $=7.0 \mathrm{~Hz}, 2 \mathrm{H}), 7.72-7.70(\mathrm{~m}, 2 \mathrm{H}), 6.96(\mathrm{~d}, J=$ $9.0 \mathrm{~Hz}, 2 \mathrm{H}), 6.88(\mathrm{~d}, J=9.3 \mathrm{~Hz}, 1 \mathrm{H})$, 4.04-3.99 (m, 4H), $2.27(\mathrm{~s}, 3 \mathrm{H}), 1.85-1.77(\mathrm{~m}$, $4 \mathrm{H}), 1.52-1.28(\mathrm{~m}, 20 \mathrm{H}), 0.89-0.86(\mathrm{~m}, 6 \mathrm{H})$. ${ }^{13} \mathrm{C}$ NMR $\left(125 \mathrm{MHz}, \mathrm{CDCl}_{3}\right): \delta 161.1,159.5$, $147.0,146.4,127.5,124.2,123.5,123.4$, $114.7,110.5,68.3,68.3,31.8,29.3,29.2,26.1$, $26.0,22.7,16.4,14.1$.

\section{4,4'-Dinonyloxy-3-methylazobenzene (AZ-OC9)}

A solution of AZ-OH (0.137 g, $0.6 \mathrm{mmol})$, 1-bromononane $(0.273 \mathrm{~g}, 1.3 \mathrm{mmol})$, and potassium carbonate $(0.66 \mathrm{~g}, 4.8 \mathrm{mmol})$ in acetonitrile $(10 \mathrm{~mL})$ was refluxed with stirring for $6 \mathrm{~h}$. Then, the mixture was allowed to cool to $\mathrm{rt}$ and the resulting residue was washed with acetone. The solvent was removed under reduced pressure. The resulting residue was extracted with chloroform and organic layer was collected. The residue was purified by GPC to give 4,4'-dinonyloxy-3-methylazobenzene

(AZ-OC9) $(0.24 \mathrm{~g}, 83 \%)$ as orange crystalline solid. ${ }^{1} \mathrm{H}$ NMR $\left(400 \mathrm{MHz}, \mathrm{CDCl}_{3}\right): \delta 7.83(\mathrm{~d}$, $J=6.9 \mathrm{~Hz}, 2 \mathrm{H}), 7.72-7.70(\mathrm{~m}, 2 \mathrm{H}), 6.96(\mathrm{~d}, J$ $=6.9 \mathrm{~Hz}, 2 \mathrm{H}), 6.88(\mathrm{~d}, J=6.2 \mathrm{~Hz}, 1 \mathrm{H})$, 4.04-3.99 (m, 4H), $2.27(\mathrm{~s}, 3 \mathrm{H}), 1.85-1.76(\mathrm{~m}$, 4H), 1.48-1.27 (m, 24H), 0.89-0.86 (m, 6H). ${ }^{13} \mathrm{C}$ NMR $\left(125 \mathrm{MHz}, \mathrm{CDCl}_{3}\right): \delta 161.1,159.1$, $147.0,146.4,127.5,124.2,123.5,123.4$, $114.7,110.5,68.3,68.3,31.9,29.5,29.4,29.2$, $26.1,26.0,22.7,16.4,14.1$.

\section{4,4'-Diundecyloxy-3-methylazobenzene}

\section{(AZ-OC11)}

A solution of AZ-OH (0.137 g, $0.6 \mathrm{mmol})$, 1-bromoundecane $(0.310 \mathrm{~g}, 1.32 \mathrm{mmol})$, and potassium carbonate $(0.66 \mathrm{~g}, 4.8 \mathrm{mmol})$ in acetonitrile $(10 \mathrm{~mL})$ was refluxed with stirring for $6 \mathrm{~h}$. Then, the mixture was allowed to cool to $\mathrm{rt}$ and the resulting residue was washed with acetone. The solvent was removed under reduced pressure. The resulting residue was extracted with chloroform and organic layer was collected. The residue was purified by GPC to give 4,4'-diundecyloxy-3-methylazobenzene (AZ-OC11) $(0.25 \mathrm{~g}, \quad 76 \%)$ as orange crystalline solid. ${ }^{1} \mathrm{H}$ NMR $\left(400 \mathrm{MHz}, \mathrm{CDCl}_{3}\right)$ : $\delta 7.83(\mathrm{~d}, J=6.9 \mathrm{~Hz}, 2 \mathrm{H}), 7.72-7.70(\mathrm{~m}, 2 \mathrm{H})$, $6.96(\mathrm{~d}, J=6.9 \mathrm{~Hz}, 2 \mathrm{H}), 6.88(\mathrm{~d}, J=6.1 \mathrm{~Hz}$, $1 \mathrm{H}), \quad 4.04-3.99(\mathrm{~m}, \quad 4 \mathrm{H}), 2.27(\mathrm{~s}, 3 \mathrm{H})$, 1.85-1.76 (m, 4H), 1.49-1.26 (m, 32H), 0.89-0.86 (m, 6H). ${ }^{13} \mathrm{C}$ NMR (125 MHz, $\left.\mathrm{CDCl}_{3}\right): \delta 161.1,159.5,147.0,146.4,127.5$, $124.2,123.5,123.4,114.7,110.5,68.3,68.3$, $31.9,29.6,29.4,29.3,29.3,29.2,26.1,26.0$, $22.7,16.4,14.1$.

\section{4,4'-Ditridecyloxy-3-methylazobenzene}

\section{(AZ-OC13)}

A solution of AZ-OH (0.456 g, $2.0 \mathrm{mmol})$, 1-bromotridecane (1.16 g, $4.4 \mathrm{mmol})$, and potassium carbonate $(2.21 \mathrm{~g}, 16.0 \mathrm{mmol})$ in acetone $(20 \mathrm{~mL})$ was heated with stirring at $60{ }^{\circ} \mathrm{C}$ for $17 \mathrm{~h}$. Then, the mixture was allowed to cool to $\mathrm{rt}$ and the solvent was removed under reduced pressure. The resulting residue was subjected to column chromatography (silica gel, ethyl acetate:hexane 1:9) to give 4,4'-ditridecyloxy-3-methylazobenzene

(AZ-OC13) (1.00 g, 82\%) as orange crystalline solid. ${ }^{1} \mathrm{H}$ NMR $\left(500 \mathrm{MHz}, \mathrm{CDCl}_{3}\right)$ : $\delta 7.83(\mathrm{~d}, J=9.0 \mathrm{~Hz}, 2 \mathrm{H}), 7.72-7.70(\mathrm{~m}, 2 \mathrm{H})$, $6.96(\mathrm{~d}, J=9.1 \mathrm{~Hz}, 2 \mathrm{H}), 6.88(\mathrm{~d}, J=9.4 \mathrm{~Hz}$, $1 \mathrm{H}), \quad 4.03-3.99(\mathrm{~m}, 4 \mathrm{H}), 2.27(\mathrm{~s}, 3 \mathrm{H})$, 1.85-1.76 (m, 4H), 1.49-1.25 (m, 40H), 0.88-0.85 (m, 6H). ${ }^{13} \mathrm{C}$ NMR (125 MHz, $\left.\mathrm{CDCl}_{3}\right): \delta 161.0,159.4,147.0,146.4,127.5$, $124.2,123.4,114.6,110.5,68.3,68.2,31.9$, $29.6,29.6,29.4,29.3,29.2,26.1,26.0,22.7$, $16.4,14.1$.

\section{4,4'-Ditetradecyloxy-3-methylazobenzene}

\section{(AZ-OC14)}

A solution of AZ-OH (0.456 g, $2.0 \mathrm{mmol})$, 1-bromotetradecane $(1.22 \mathrm{~g}, 4.4 \mathrm{mmol})$, and potassium carbonate $(2.21 \mathrm{~g}, 16.0 \mathrm{mmol})$ in acetone $(20 \mathrm{~mL})$ was heated with stirring at $60{ }^{\circ} \mathrm{C}$ for $17 \mathrm{~h}$. Then, the mixture was allowed to cool to $\mathrm{rt}$ and the resulting residue was washed with chloroform. The eluent was concentrated under reduced pressure and recrystallized from acetone to give 4,4'-ditetradecyloxy-3-methylazobenzene 
(AZ-OC14) (1.18 g, 93\%) as orange crystalline solid. ${ }^{1} \mathrm{H}$ NMR $\left(400 \mathrm{MHz}, \mathrm{CDCl}_{3}\right)$ : $\delta 7.83(\mathrm{~d}, J=8.9 \mathrm{~Hz}, 2 \mathrm{H}), 7.72-7.70(\mathrm{~m}, 2 \mathrm{H})$, $6.96(\mathrm{~d}, J=9.0 \mathrm{~Hz}, 2 \mathrm{H}), 6.88$ (d, $J=9.4 \mathrm{~Hz}$, $1 \mathrm{H}), \quad 4.03-3.99 \quad(\mathrm{~m}, \quad 4 \mathrm{H}), \quad 2.27 \quad(\mathrm{~s}, \quad 3 \mathrm{H})$, 1.85-1.76 (m, 4H), 1.49-1.23 (m, 44H), 0.87-0.84 (m, 6H). ${ }^{13} \mathrm{C}$ NMR $(125 \mathrm{MHz}$, $\left.\mathrm{CDCl}_{3}\right): \delta 161.0,159.4,147.0,146.4,127.5$, $124.2,123.4,114.6,110.5,68.3,68.2,31.9$, $29.7,29.6,29.4,29.3,29.2,26.1,26.0,22.7$, $16.4,14.1$.

\section{4,4'-Dipendadecyloxy-3-methylazobenzene (AZ-OC15)}

A solution of AZ-OH (0.343 g, $1.5 \mathrm{mmol})$, 1-bromopentadecane $(0.96 \mathrm{~g}, 3.3 \mathrm{mmol})$, and potassium carbonate $(1.66 \mathrm{~g}, 12.0 \mathrm{mmol})$ in acetone $(15 \mathrm{~mL})$ was heated with stirring at $60{ }^{\circ} \mathrm{C}$ for $19 \mathrm{~h}$. Then, the mixture was allowed to cool to $\mathrm{rt}$ and the resulting residue was washed with chloroform. The eluent was concentrated under reduced pressure and recrystallized from acetone to give 4,4'-dipendadecyloxy-3-methylazobenzene

(AZ-OC15) (0.94 g, 96\%) as orange crystalline solid. ${ }^{1} \mathrm{H}$ NMR $\left(500 \mathrm{MHz}, \mathrm{CDCl}_{3}\right)$ : $\delta 7.84(\mathrm{~d}, J=9.0 \mathrm{~Hz}, 2 \mathrm{H}), 7.72-7.70(\mathrm{~m}, 2 \mathrm{H})$, $6.96(\mathrm{~d}, J=9.0 \mathrm{~Hz}, 2 \mathrm{H}), 6.88(\mathrm{~d}, J=9.4 \mathrm{~Hz}$, $1 \mathrm{H}), \quad 4.03-3.99(\mathrm{~m}, 4 \mathrm{H}), 2.27(\mathrm{~s}, 3 \mathrm{H})$, 1.85-1.76 (m, 4H), 1.49-1.23 (m, 48H), 0.88-0.85 (m, 6H). ${ }^{13} \mathrm{C}$ NMR (125 MHz, $\left.\mathrm{CDCl}_{3}\right): \delta 161.0,159.4,147.0,146.4,127.5$, $124.2,123.4,114.6,110.5,68.3,68.2,31.9$, $29.7,29.7,29.6,29.4,29.3,29.2,26.1,26.0$, $22.7,16.4,14.1$.

\section{4,4'-Dihexadecyloxy-3-methylazobenzene (AZ-OC16)}

A solution of AZ-OH (0.343 g, $1.5 \mathrm{mmol})$, 1-bromohexadecane $(1.01 \mathrm{~g}, 3.3 \mathrm{mmol})$, and potassium carbonate $(1.66 \mathrm{~g}, 12.0 \mathrm{mmol})$ in acetone $(15 \mathrm{~mL})$ was heated with stirring at $60{ }^{\circ} \mathrm{C}$ for $19 \mathrm{~h}$. Then, the mixture was allowed to cool to $\mathrm{rt}$ and the resulting residue was washed with chloroform. The eluent was concentrated under reduced pressure and recrystallized from acetone to give 4,4'-dihexadecyloxy-3-methylazobenzene

(AZ-OC16) $\quad(0.99 \mathrm{~g}, \quad 97 \%)$ as orange crystalline solid. ${ }^{1} \mathrm{H}$ NMR $\left(400 \mathrm{MHz}, \mathrm{CDCl}_{3}\right)$ : $\delta 7.83(\mathrm{~d}, J=8.9 \mathrm{~Hz}, 2 \mathrm{H}), 7.72-7.70(\mathrm{~m}, 2 \mathrm{H})$, $6.96(\mathrm{~d}, J=9.0 \mathrm{~Hz}, 2 \mathrm{H}), 6.88(\mathrm{~d}, J=9.4 \mathrm{~Hz}$, $1 \mathrm{H}), \quad 4.03-3.99 \quad(\mathrm{~m}, \quad 4 \mathrm{H}), \quad 2.27 \quad(\mathrm{~s}, 3 \mathrm{H})$,
1.85-1.76 (m, 4H), 1.49-1.23 (m, 52H), 0.87-0.84 (m, 6H). ${ }^{13} \mathrm{C}$ NMR (125 MHz, $\left.\mathrm{CDCl}_{3}\right): \delta 161.0,159.4,147.0,146.4,127.5$, $124.2,123.4,114.6,110.5,68.3,68.2,31.9$, $29.7,29.7,29.6,29.4,29.3,29.2,26.1,26.0$, $22.7,16.4,14.1$.

\section{4,4'-Diheptadecyloxy-3-methylazobenzene (AZ-OC17)}

A solution of AZ-OH (0.228 g, $1.0 \mathrm{mmol})$, 1-bromoheptadecane $(0.70 \mathrm{~g}, 2.2 \mathrm{mmol})$, and potassium carbonate $(1.10 \mathrm{~g}, 8.0 \mathrm{mmol})$ in acetone $(10 \mathrm{~mL})$ was heated with stirring at $60{ }^{\circ} \mathrm{C}$ for $15 \mathrm{~h}$. Then, the mixture was allowed to cool to $\mathrm{rt}$ and the resulting residue was washed with chloroform. The eluent was concentrated under reduced pressure and recrystallized from acetone to give 4,4'-diheptadecyloxy-3-methylazobenzene

(AZ-OC17) $\quad(0.62 \mathrm{~g}, \quad 88 \%)$ as orange crystalline solid. ${ }^{1} \mathrm{H}$ NMR $\left(500 \mathrm{MHz}, \mathrm{CDCl}_{3}\right)$ : $\delta 7.83(\mathrm{~d}, J=8.3 \mathrm{~Hz}, 2 \mathrm{H}), 7.72-7.68(\mathrm{~m}, 2 \mathrm{H})$, $6.96(\mathrm{~d}, J=8.3 \mathrm{~Hz}, 2 \mathrm{H}), 6.88(\mathrm{~d}, J=8.9 \mathrm{~Hz}$, $1 \mathrm{H}), \quad 4.03-3.99(\mathrm{~m}, \quad 4 \mathrm{H}), \quad 2.27 \quad(\mathrm{~s}, \quad 3 \mathrm{H})$, 1.85-1.76 (m, 4H), 1.49-1.23 (m, 56H), 0.87-0.84 (m, 6H). ${ }^{13} \mathrm{C}$ NMR $(125 \mathrm{MHz}$, $\left.\mathrm{CDCl}_{3}\right): \delta 161.0,159.4,147.0,146.4,127.5$, $124.2,123.4,114.6,110.5,68.3,68.3,31.9$, $29.7,29.6,29.4,29.2,26.1,26.0,22.7,16.4$, 14.1 .

\section{4,4'-Dioctadecyloxy-3-methylazobenzene} (AZ-OC18)

A solution of AZ-OH (0.228 g, $1.0 \mathrm{mmol})$, 1-bromooctadecane $(2.2 \mathrm{~g}, 6.6 \mathrm{mmol})$, and potassium carbonate $(1.52 \mathrm{~g}, 11.0 \mathrm{mmol})$ in DMF $(5.5 \mathrm{~mL})$ was heated with stirring at $80{ }^{\circ} \mathrm{C}$ for $2 \mathrm{~h}$. Then, the mixture was allowed to cool to $\mathrm{rt}$ and stirred for $16 \mathrm{~h}$. The solvent was removed under reduced pressure. The residue was extracted with ethyl acetate and washed with water and brine before being dried $\left(\mathrm{MgSO}_{4}\right)$, filtrated and concentrated under reduced pressure. The resulting residue was subjected to column chromatography (silica gel, chloroform:hexane 1:4) to give 4,4'-dioctadecyloxy-3-methylazobenzene

(AZ-OC18) $(0.56 \mathrm{~g}, 76 \%)$ as orange crystalline solid. ${ }^{1} \mathrm{H}$ NMR $\left(400 \mathrm{MHz}, \mathrm{CDCl}_{3}\right)$ : $\delta 7.89(\mathrm{~d}, J=9.0 \mathrm{~Hz}, 2 \mathrm{H}), 7.76-7.78(\mathrm{~m}, 2 \mathrm{H})$, $6.97(\mathrm{~d}, J=9.0 \mathrm{~Hz}, 2 \mathrm{H}), 6.89(\mathrm{~d}, J=8.4 \mathrm{~Hz}$, $1 \mathrm{H}), \quad 3.99-4.04 \quad(\mathrm{~m}, \quad 4 \mathrm{H}), 2.27(\mathrm{~s}, 3 \mathrm{H})$, $1.77-1.83(\mathrm{~m}, 4 \mathrm{H}), \quad 1.42-1.51 \quad(\mathrm{~m}, 4 \mathrm{H})$, 
1.23-1.38 (m, 56H), 0.84-0.88 (m, 6H). ${ }^{13} \mathrm{C}$ NMR $\left(125 \mathrm{MHz}, \mathrm{CDCl}_{3}\right): \delta 161.3,159.7$, $146.6,146.0,127.6,124.4,123.7,123.6$, $114.7,110.6,68.4,68.3,31.9,29.7,29.7,29.6$, $29.4,29.3,29.2,26.1,26.0,22.7,16.4,14.1$.

\subsection{Instrumentation}

$\mathrm{UV} / \mathrm{vis}$ absorption spectra were measured by a Shimadzu UV3100S spectrophotometer. Differential scanning calorimetry (DSC) was measured by a SII Nanotechnology DSC6100. the scan rate was $2 \mathrm{~K} \mathrm{~min}^{-1}$. NMR spectra were measured by a Bruker Avance 400 or 500 . Polarizing optical photomicrographs (POM) were taken by an OLYMPUS BX51 microscope equipped with a high pressure $\mathrm{Hg}$ lamp, optical filters and heat absorbing filters so that in-situ observation on photoirradiation was possible (365 and $436 \mathrm{~nm}$ were used). Other photoirradiation experiments were performed by an LED's (Asahi Spectra Inc. POT-365 LED for $365 \mathrm{~nm}$, home built LED for $450 \mathrm{~nm}$ ). Sample temperature was controlled by a heating/cooling stage Linkam 10033L. Light intensity was monitored by a Newport 1917-R optical power meter with 818-ST-UV photodetector or USHIO accumulated UV meter UIT-250.

The tensile shear strengths were measured using a Shimadzu Autograph tensile-testing machine with a $1-\mathrm{kN}$ load cell, SLBL-1kN, and a holding apparatus, SCG-1kNA. Two 1.5 $\mathrm{cm} \times 5 \mathrm{~cm}, 1 \mathrm{~mm}$-thick glass slides connected to $0.2 \mathrm{~mm}$-thick stainless-steel plates were bonded together by spreading $2-3 \mathrm{mg}$ of the azobenzene over a $1.5 \mathrm{~cm} \times 1.5 \mathrm{~cm}$ area of the slides and pressing the slides together. The glass slides were pulled in opposite directions at $0.2 \mathrm{~mm} \mathrm{~min}^{-1}$, and the stress was monitored during separation with the tensiletesting machine. Adhesion forces were determined as average values for three times measurement.

\subsection{Photosensitivity Evaluation}

To evaluate the photosensitivity of the series of azobenzenes, we optically measured the extent of the photoinduced solid-liquid phase transition by monitoring the light intensity of $650 \mathrm{~nm}$ transmitted through a film sample that is placed between two polarizers at a crossed configuration. We used the polarizing optical microscope system as shown in Figure 2a. We used a microspectroscopy setup based on an OLYMPUS BX51 microscope. During the measurement, the sample was irradiated with $365 \mathrm{~nm}$ simultaneously. The UV light source is a ultra-high pressure $\mathrm{Hg}$ lamp. As for the monitoring light, we used a back light of the microscope through an optical filter to cut off the light with shorter wavelength $(<600 \mathrm{~nm})$. The monitoring light was monitored by an Ocean Optics USB2000 spectrophotometer through an optical fiber. We used a sample cell (EHC Inc.) with a sample thickness of 0.6 $\mu \mathrm{m}$. The cell was filled with the sample at above melting temperature of the sample, then cooled to room temperature. We obtained kinetic profile of the loss of birefringence. The area of the irradiation with $365 \mathrm{~nm}$ is much larger than that of the monitoring with $650 \mathrm{~nm}$. Typical time profiles obtained in this experiment are shown in Figure $2 b$.
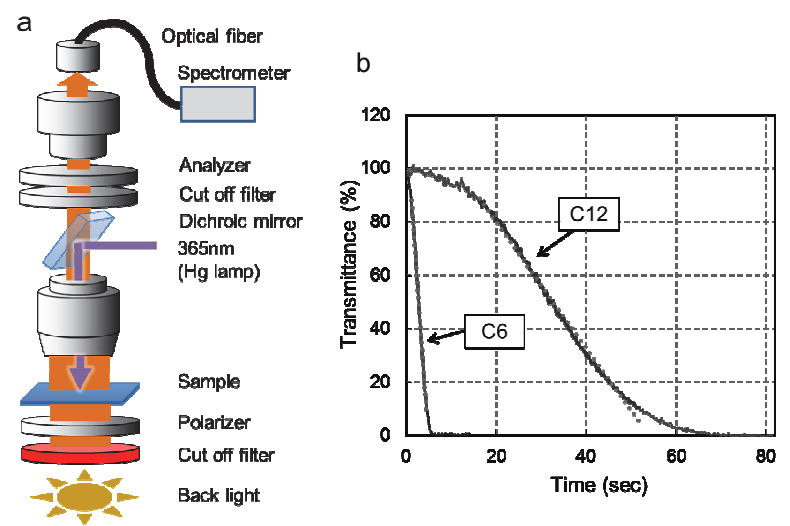

Fig. 2. (a) Schematic diagram for the system for the photosensitivity evaluation. We used a microspectroscopy setup. (b) Typical data obtained by the system shown in (a). Time profiles of AZ-OC6 and AZ-OC12 when irradiated with $365 \mathrm{~nm}$. It clearly shows that AZ-OC6 exhibits faster photoresponse than AZ-OC12.

\section{Results and Discussion}

\subsection{Thermal phase transition}

All compounds were synthesized via two conventional reactions (diazo coupling and alkylation) in good yields from commercial available reagents. The thermal phase transition behavior was analyzed by the DSC and the result is listed in Table 1 and summarized in Figure 3. All compounds exhibited crystalline solids at room 
temperature. Interestingly, the melting point (Cr-Iso or Cr-N transitions) prominently decreases when the alkyl chain length becomes longer in the region of $\mathrm{Cn}=1-8$. On the other hand, the melting point gradually increases in the longer chain region $(\mathrm{Cn}=$ 8-18). Rather complicated phase transition behavior was observed in the region of $\mathrm{Cn}=$ 5-12. Metastable crystal phase was observed in AZ-OC6, AZ-OC8, AZ-OC9, AZ-OC10, and AZ-OC11. Also, crystal polymorphism was observed in AZ-OC5, AZ-OC7, AZ-OC8, AZ-OC10, and AZ-OC11. Above the melting

points, nematic liquid crystalline phase was observed in AZ-OC7, AZ-OC8, AZ-OC9, AZ-OC10, AZ-OC11, and AZ-OC12. These nematic phases were observed in between 60 and $80^{\circ} \mathrm{C}$.

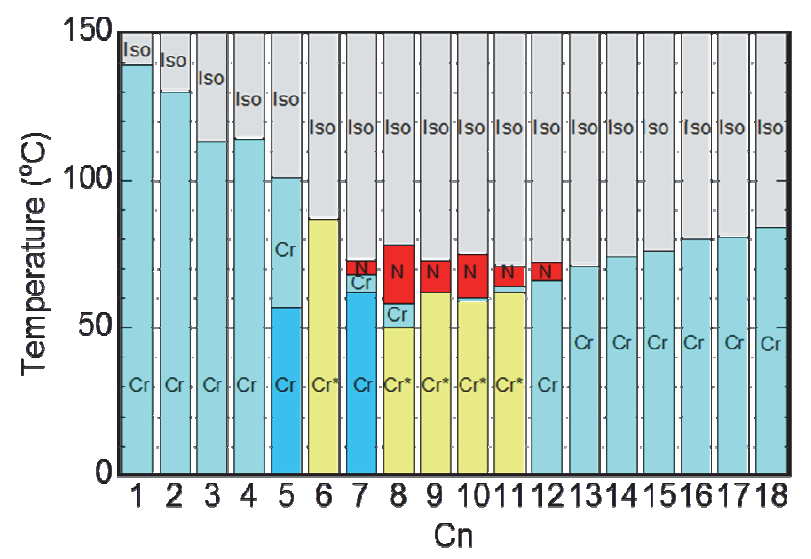

Fig. 3. Thermal phase transition temperature of AZ-OCn measured by DSC at the second heating process. $\mathrm{Cr}, \mathrm{Cr}^{*}, \mathrm{~N}$, and Iso denote crystal, metastable crystal, nematic liquid crystal, and isotropic phases, respectively.

\subsection{Photosensitivity Evaluation}

Figure 4 shows the photoinduced phase transition of AZ-OC8 observed by POM. The irradiation with $365 \mathrm{~nm}$ light induces liquefaction and the sample lost birefringence. In contrary, the crystal reappeared when it was irradiated with $436 \mathrm{~nm}$. Other compounds also exhibited similar photoresponse, although the time required for the liquefaction were varied with compounds. To compare the rate of the photoinduced solid-liquid phase transition in the series of azobenzenes, we measured the loss of birefringence optically when a crystalline film sample was irradiated with UV light. The
Table 1. Thermal Phase Transition Temperature of AZ-OCn Measured by DSC.

\begin{tabular}{ccc}
\hline $\mathrm{n}$ & Heating $^{a}$ & Cooling $^{b}$ \\
\hline 1 & Cr 139 Iso & Iso 122 Cr \\
2 & Cr 130 Iso & Iso 124 Cr \\
3 & Cr 113 Iso & Iso 90 Cr \\
4 & Cr 114 Iso & Iso 89 Cr \\
5 & Cr 57 Cr 101 Iso & Iso 79 Cr 55 Cr \\
6 & Cr 87 Iso & Iso 78 Cr \\
7 & Cr 62 Cr 68 N 73 Iso & Iso 73 N 64 Cr 55 Cr \\
8 & Cr 50 Cr 58 N 78 Iso & Iso 78 N 56 Cr \\
9 & Cr 62 N 73 Iso & Iso 73 N 52 Cr \\
10 & Cr 59 Cr 60 N75 Iso & Iso 74 N 51 Cr 36 Cr \\
11 & Cr 62 Cr 64 N 71 Iso & Iso 71 N 50 Cr 47 Cr \\
12 & Cr 66 N 72 Iso & Iso 72 N 53 Cr \\
13 & Cr 71 Iso & Iso 70 N 54 Cr \\
14 & Cr 74 Iso & Iso 71 X 61 Cr \\
15 & Cr 76 Iso & Iso 70 X 63 X 62 Cr \\
16 & Cr 80 Iso & Iso 71 X 66 X 63 Cr \\
17 & Cr 81 Iso & Iso 70 X 68 X 64 Cr \\
18 & Cr 84 Iso & Iso 70 X 68 Cr \\
\hline
\end{tabular}

${ }^{a}$ Second heating process. ${ }^{b}$ First cooling process. Cr: Crystal phase. N: Nematic liquid crystal phase. Iso: Isotropic phase. X: unidentified phase.

experimental setup is shown in Figure $2 \mathrm{a}$ and detail is described in the Experimental section. Typical example of the time trace is shown in Figure $2 \mathrm{~b}$. Intuitively, one can recognize that AZ-OC6 shows faster photoresponse than AZ-OC12. Most portion of the time profile exhibits linear component. Since the photoinduced solid-liquid phase transition is considered to take place from the surface of the crystal [12], and the retardation value is proportional to the film thickness, we plotted the slope of the time profile. Figure 5 shows the plot showing the relative photoresponse among azobenzenes with different alkyl
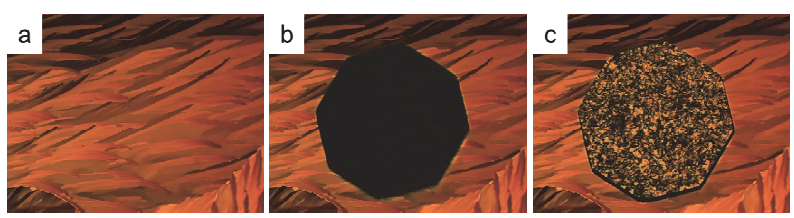

Fig. 4. Polarizing optical photomicrographs of crystalline film of AZ-OC8 a) before irradiation, b) after irradiation with $365 \mathrm{~nm}(3 \mathrm{sec})$, and c) after irradiation with $436 \mathrm{~nm}(2 \mathrm{sec})$ to b).

chains. It is quite interesting that the azobenzenes with alkyl chain length of 6-10 showed relatively fast photoinduced 
solid-liquid phase transition than that with shorter $(\mathrm{Cn}=1-5)$ and longer $(\mathrm{Cn}=11-18)$

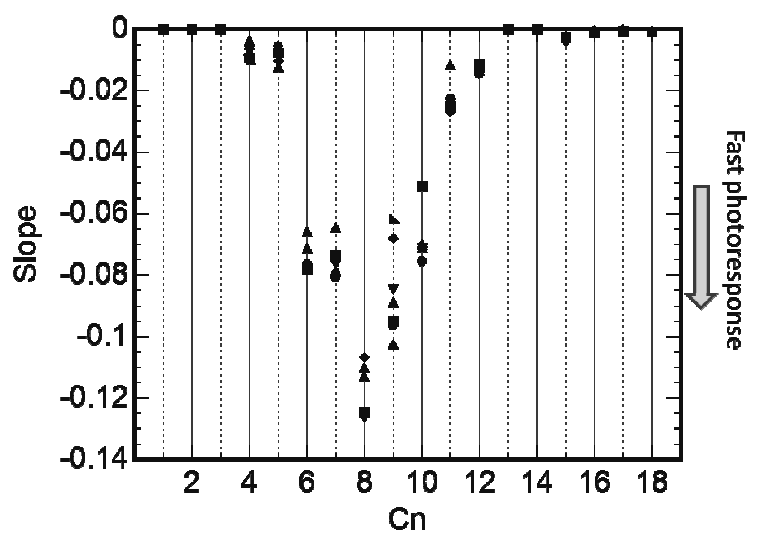

Fig. 5. Plot of relative photoresponse of AZ-OCn.

ones. In addition, the difference of only one carbon atom drastically alters the photoresponse between AZ-OC5 and

AZ-OC6. It required more than 3 minutes of irradiation to liquefy AZ-OC5, while only 4 seconds liquefied AZ-OC6 completely. Crystal packing and dynamics of molecules are important factors for the photoinduced solid-liquid phase transition [12]. Metastable crystals may play an important role for the phase transition. We are currently investigating the relationship between the crystal structure and the photoresponse and will be published elsewhere.

Since the deactivation process of photoexcited molecules involves dissipation of energy as heat, a temperature increase cannot be avoided. To confirm that the heating effects are not the main reason for the liquefaction, an irradiation experiment at various intensity of light $(5-408 \mathrm{~mW}$ $\mathrm{cm}^{-2}$ ) was carried out by using AZ-OC6. We observed the phase transition with almost no intensity dependence and complete liquefaction were observed at the same total dose $\left(3 \mathrm{~J} \mathrm{~cm}^{-2}\right)$. Therefore the heating effects are not the main reason for the liquefaction but photochemical reaction.

\subsection{Adhesion Force Evaluation}

Two glass slides containing an azobenzene were thermally fused above its melting point and the sample was allowed to cool to room temperature. Then we carried out the tensile lap-shear adhesive strength test (pulling test) before, after the irradiation with $365 \mathrm{~nm}\left(80 \mathrm{~mW} \mathrm{~cm} \mathrm{~cm}^{-2}, 3 \mathrm{~min}\right)$, and after $450 \mathrm{~nm}\left(40 \mathrm{~mW} \mathrm{~cm}^{-2}, 3 \mathrm{~min}\right)$.

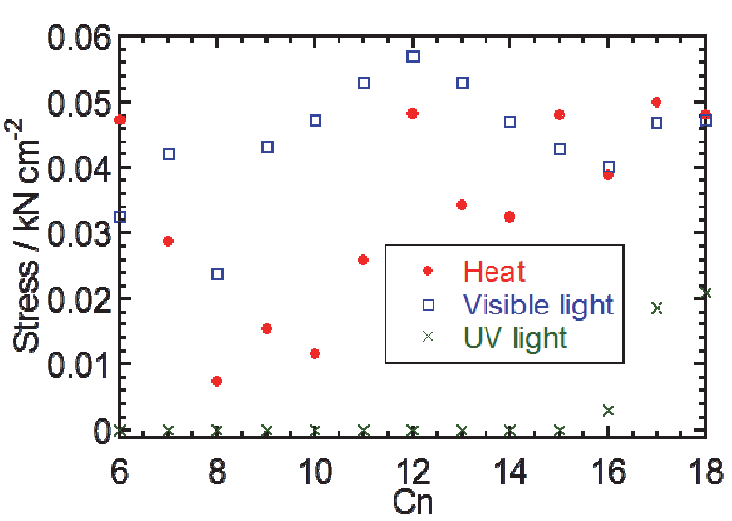

Fig. 6. Adhesion strength of AZ-OCn before irradiation (circle), after the irradiation with 365 $\mathrm{nm}$ (cross), and after the irradiation with $450 \mathrm{~nm}$ (square).

The adhesion strength of the initial (nonirradiated) condition was varied with the alkyl chain length: azobenzenes with $\mathrm{Cn}=8-10$ exhibited minimal values $\left(10-15 \mathrm{~N} \mathrm{~cm}^{-2}\right)$ and others showed higher values of $30-50 \mathrm{~N} \mathrm{~cm}^{-2}$. As expected, the adhesion force decreased to $0 \mathrm{~N} \mathrm{~cm}^{-2}$ when the sample was irradiated with $365 \mathrm{~nm}$ light. However, azobenzenes with $\mathrm{Cn}=16-18$ showed small adhesion force. It may be because the photoinduced phase transition was not complete at this experimental condition. Interestingly, after the irradiation with $450 \mathrm{~nm}$ light, the adhesion values recovered and even higher values were observed. This kind of recovery was also observed previously [22]. Since the sample is in crystalline nature, the adhesion strength might be related to the crystal grain size and how the crystal grow along the glass wall. Actually, the photochemically generated crystal grains were smaller than thermally generated ones. Overall, it was demonstrated that the adhesion strength was switched by UV and visible light irradiation.

\section{Conclusion}

The photoinduced solid-liquid phase transitions were investigated in rod-shaped azobenzenes having a methyl group at the 3 -position and alkoxy groups with different chain length at the 4- and 4'-positions. Thermal and photochemical properties, and adhesive properties were investigated. It was found that the azobenzenes with alkyl chain with medium length $(\mathrm{Cn}=6-10)$ showed relatively fast photoinduced solid-liquid phase transition. Irradiation with UV light (365 $\mathrm{nm}$ ) induced the phase transition to the 
liquid phase and the tensile shear strength values decreased to almost zero. The irradiation with visible light $(450 \mathrm{~nm})$ recovered the adhesion strength. The molecular design criteria shown in this study will be useful for designing more sophisticated photofunctional materials. In addition, the method for the evaluation of the phase transition is useful for especially molecular systems those show birefringence such as crystals.

\section{Acknowledgements}

This work was supported in part by JSPS/MEXT KAKENHI (23760680, 26620152, 26288096), Iketani Science and Technology Foundation, and The Canon Foundation.

\section{References}

1. H. Yu, T. Ikeda, Adv. Mater., 23 (2011) 2149.

2. T. Kato, Y. Hirai, S. Nakaso, M. Moriyama, Chem. Soc. Rev., 36 (2007) 1857.

3. T. Ikeda, J. Mamiya, Y. Yu, Angew. Chem. Int. Ed. Engl., 46 (2007) 506.

4. S. Yagai, A. Kitamura, Chem. Soc. Rev., 37 (2008) 1520.

5. S. Lee, H.S. Kang, J.-K. Park, Adv. Mater., 24 (2012) 2069.

6. T. Seki, Bull. Chem. Soc. Jpn., 80 (2007) 2084.

7. M. Tsuda, K. Kuratani, Bull. Chem. Soc. Jpn., 37 (1964) 1284.

8. K. Nakayama, L. Jiang, T. Iyoda, K. Hashimoto, A. Fujishima, Jpn. J. Appl. Phys., 36 (1997) 3898.

9. K. Ichimura, Chem. Commun., (2009) 1496.

10. Y. Norikane, Y. Hirai, M. Yoshida, Chem. Commun., 47 (2011) 1770.

11. E. Uchida, K. Sakaki, Y. Nakamura, R.
Azumi, Y. Hirai, H. Akiyama, M. Yoshida, Y. Norikane, Chem. - A Eur. J., 19 (2013) 17391.

12. M. Hoshino, E. Uchida, Y. Norikane, R. Azumi, S. Nozawa, A. Tomita, T. Sato, S. Adachi, S. Koshihara, J. Am. Chem. Soc., 136 (2014) 9158.

13. Y. Norikane, J. Photopolym. Sci. Technol., 25 (2012) 153.

14. Y. Okui, M. Han, Chem. Commun., 48 (2012) 11763 .

15. M. Baroncini, S. D’Agostino, G. Bergamini, A. Ceroni, Paola Comotti, P. Sozzani, T.M. Bassanetti, Irene Grepioni, Fabrizia Hernandez, M. Silvi, Serena Venturi, A. Credi, Nat. Chem., 7 (2015) 634.

16. K. Ishiba, M. Morikawa, C. Chikara, T. Yamada, K. Iwase, M. Kawakita, N. Kimizuka, Angew. Chem. Int. Ed. Engl., 54 (2015) 1532.

17. D.-Y. Kim, S. Lee, H. Kim, S. Min Kim, N. Kim, K. Jeong, Chem. Commun., 51 (2015) 11080.

18. E. Uchida, R. Azumi, Y. Norikane, Chem. Lett., 43 (2014) 1619.

19. H. Akiyama, M. Yoshida, Adv. Mater., 24 (2012) 2353.

20. H. Akiyama, M. Yoshida, H. Kihara, Y. Norikane, R. Azumi, J. Photopolym. Sci. Technol., 27 (2014) 301.

21. H. Akiyama, S. Kanazawa, M. Yoshida, H. Kihara, H. Nagai, Y. Norikane, R. Azumi, Mol. Cryst. Liq. Cryst., 604 (2014) 64.

22. H. Akiyama, S. Kanazawa, Y. Okukyama, M. Yoshida, H. Kihara, H. Nagai, Y. Norikane, R. Azumi, ACS Appl. Mater. Interfaces, 6 (2014) 7933.

23. Y. Norikane, E. Uchida, S. Tanaka, K. Fujiwara, E. Koyama, R. Azumi, H. Akiyama, H. Kihara, M. Yoshida, Org. Lett., 16 (2014) 5012. 